\title{
Polarity of Flagellar Growth in Salmonella
}

\author{
By T. IINO \\ National Institute of Genetics, Misima, Japan \\ (Accepted for publication 23 January 1969)
}

\begin{abstract}
SUMMARY
The phenomenon whereby Salmonella cells produce curly flagella in media containing $p$-fluorophenylalanine was used to investigate the polarity of flagellar growth. Salmonella typhimurium LT 2 in logarithmic growth in broth was transferred to minimal medium or saline, or their flagella shortened by mechanical breaking. Then, after 2 to $3 \mathrm{hr}$ at $37^{\circ}$ in a medium containing $p$-fluorophenylalanine the distributions of number, length and shape of their flagella were observed. Curly waves appeared at the distal portions of flagella. The growth rate of a flagellum decreased as its length increased, reaching zero at approximately five normal wave-numbers (about $15 \mu$ ). The growth rate of flagella shortened by mechanical breaking was not less than that of intact ones of similar length. The decline is attributed to decrease in transport efficiency with increase in length rather than to ageing of the flagellumforming apparatus.

A normal flagellar strain and a curly mutant strain of Salmonella abortusequi were grown together in broth. Numbers of both types of rods and flagella increased to $\mathrm{I} \cdot 5$-fold in $3 \mathrm{hr}$. At this stage, neither heteromorphous rods nor single flagella having both normal and curly waves were detected. Hence, flagellin molecules reach the top of a growing flagellum without being excreted into the culture medium.
\end{abstract}

\section{INTRODUCTION}

Reconstitution experiments in vitro with Salmonella flagella have shown that the flagellar filaments have structural polarity and that they grow by a sequential orderly polymerization of flagellin molecules at a structurally defined end, called the T-end, of each flagellar filament (Asakura, Eguchi \& Iino, 1968). The T-end corresponds to the distal end of a flagellum attached to the cell. Therefore, if flagellar growth in vivo is homologous with that in vitro, it must take place at the tip. The present experiments were undertaken to investigate whether or not this is the case. In order to identify newly formed parts of flagella, the phenomenon that the normal Salmonella rods produce curly flagella in the media containing $p$-fluorophenylalanine (Kerridge, I959a) was used. Data on the growth rate of flagellar filaments in vivo are reported.

\section{METHODS}

Salmonella strains LT 2, SJ 30 and SJ 25 were used. They carry peritrichous flagella in wide range of cultural conditions (Kerridge, I959 $b$; Quadling \& Stocker, 1962). Strain LT2 is the diphasic ancestor of Salmonella typhimurium SW I06I in which Kerridge (1959a, 1960) reported the production of curly flagella in media containing $p$-fluorophenylalanine (FPA) and normal flagella without FPA. sJ 30 is a curly 
flagellar mutant of $S$. abortusequi (Iino, 1962). SJ 25 is a strain in which the chromosomal region carrying flagellin-structure gene $\mathrm{H2}$-enx of sJ 30 was replaced by the homologous region of LT 2 by P 22-phage-mediated transduction. SJ 30 thus differs from SJ 25 only in flagellar characters: the former produces curly flagella of enx-antigen type while the latter normal flagella of $I$.2-antigen type.

Minimal medium (MM) consisted of $(\%, w / v): \mathrm{K}_{2} \mathrm{HPO}_{4}, 0.7 ; \mathrm{KH}_{2} \mathrm{PO}_{4}, 0.2$; sodium citrate. $5 \mathrm{H}_{2} \mathrm{O}, 0.05 ; \mathrm{MgSO}_{4} \cdot 7 \mathrm{H}_{2} \mathrm{O}, 0.0 \mathrm{I}$; and glucose 0.2 in distilled water. FPA treatment was carried out in $\mathrm{MM}$ supplemented with a complete amino acid mixture (O.I $\mathrm{mg}$ of each L-amino acid $/ \mathrm{ml}$.) in which phenylalanine was replaced by FPA I mg./ml. This medium was termed RM(FPA).

Mechanical separation of flagella from bacterial bodies was performed as follows: $4.8 \times 10^{9}$ of bacteria in $2.5 \mathrm{ml}$. saline $(\mathrm{NaCl}, 0.85 \%, \mathrm{w} / \mathrm{v})$ in a screw-capped glass tube (diameter Io mm., length $30 \mathrm{~mm}$.) were shaken for $90 \mathrm{~min}$. (750 strokes/min. with $25 \mathrm{~mm}$. amplitude) with fine glass beads. After centrifuging at $1200 \mathrm{~g}$ for $\mathrm{I} 5 \mathrm{~min}$. the pellet was suspended in an appropriate medium for further experiment.

Bacterial numbers in liquid media were counted in an Elma bacterial counting chamber. Staining and counting of flagella were by the method of Leifson (I951). Wave numbers were recorded by counting decimal fractions as units. Observations were made on 400 bacteria in each experiment.

\section{RESULTS}

Formation of curly and heteromorphous flagella by FPA treatment. The cells of Salmonella typhimurium strain L.T2 in logarithmic growth in $10 \mathrm{ml}$. broth were centrifuged and suspended in $5 \mathrm{ml}$. of $\mathrm{MM}$, incubated $\mathrm{I} \mathrm{hr}$ at $37^{\circ}$, centrifuged again

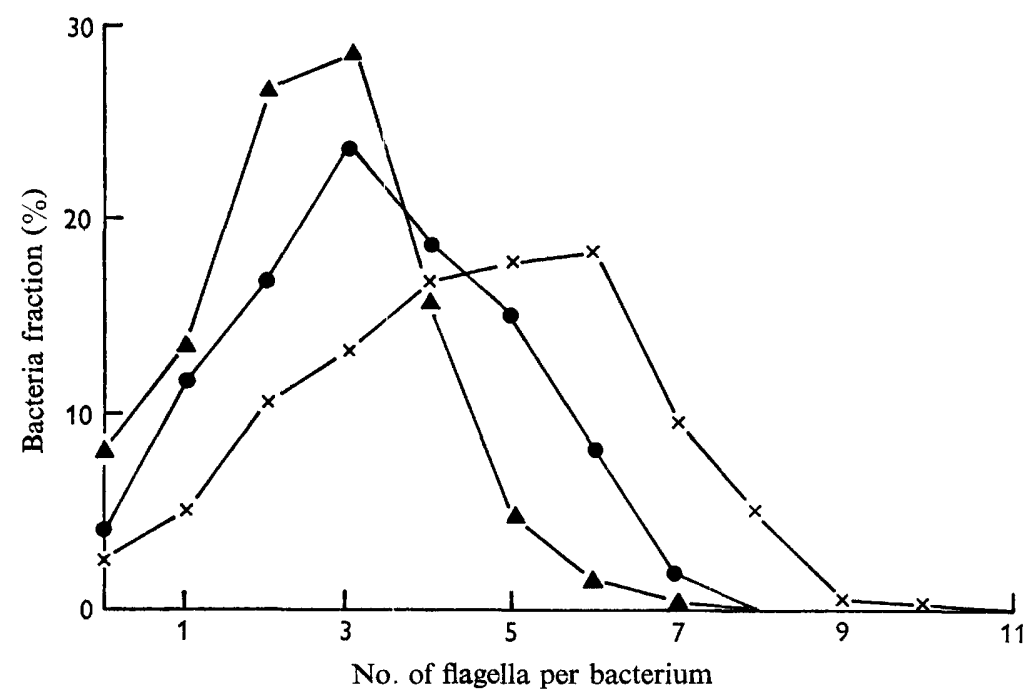

Fig. I. Changes in the distribution of flagellar number per bacterium during the growth of Salmonella typhimurium LT 2 in RM (FPA): $\times, \circ \mathrm{hr} ; 0,2 \mathrm{hr} ; \boldsymbol{\Delta}, 3 \mathrm{hr}$.

and suspended in $2 \mathrm{ml}$. of RM(FPA). The bacteria $\left(2.5 \times 10^{8} / \mathrm{ml}\right.$.) were incubated at $37^{\circ}$ without aeration. At 0,2 and $3 \mathrm{hr}$ of incubation, $0.2 \mathrm{ml}$ samples were fixed immediately by $\mathrm{I} \%(\mathrm{v} / \mathrm{v})$ formalin and the flagella stained. 
During incubation in RM(FPA), the bacteria increased to $4.1 \times 10^{8}$ and $6.0 \times 10^{8} / \mathrm{ml}$. at 2 and $3 \mathrm{hr}$, respectively, while the flagella decreased from $4.4 /$ cell at o hr to $3 \cdot 3$ and $2 \cdot 5 /$ cell at 2 and $3 \mathrm{hr}$ respectively. Therefore, flagellar numbers were calculated to have
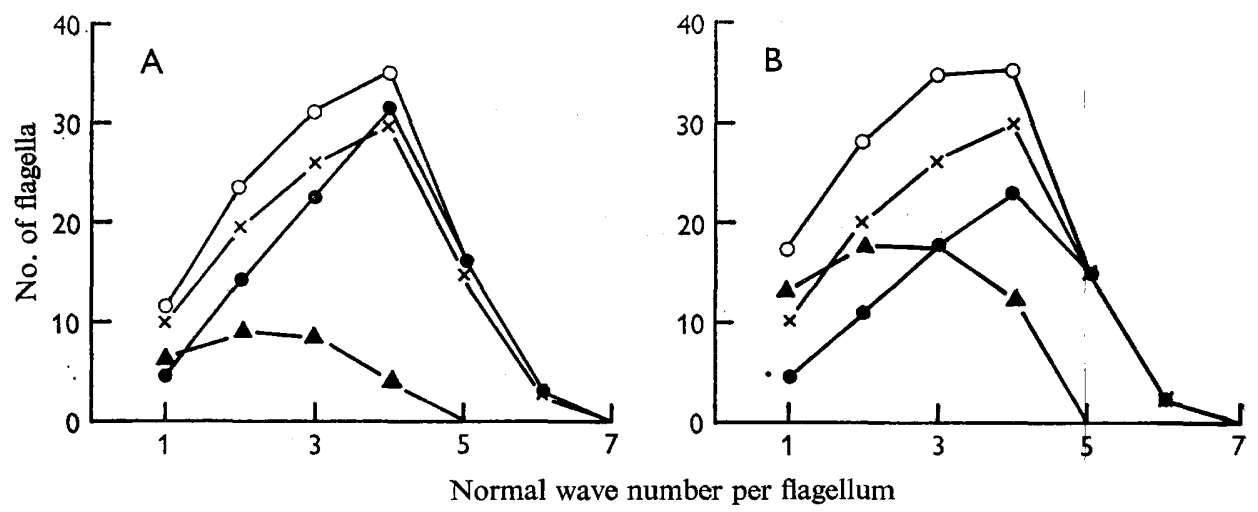

Fig. 2. Distribution of normal wave numbers among flagella of Salmonella typhimurium LT 2 grown in RM (FPA): $\times$, normal flagella at o hr; $\bullet$, normal flagella; $\boldsymbol{\Lambda}$, heteromorphous flagella; $\bigcirc$, normal plus heteromorphous flagella; $\mathrm{A}$, at $2 \mathrm{hr}, \mathrm{B}$, at $3 \mathrm{hr}$. The total number of flagella at o $\mathrm{hr}$ was taken as 100 . The numbers at 2 and $3 \mathrm{hr}$ were adjusted by multiplying the percentage of each fraction by the net increase of flagellar number during incubation; thus, the total numbers of flagella at 2 and $3 \mathrm{hr}$ were taken as 123 and 136 respectively (see Table I).

Table I. Flagellar shape of Salmonella typhimurium LT2 grown in RM(FPA)

(a) Numbers of flagella counted on 400 bacteria; $(b)$ percentage of flagella of different shapes at each incubation time; $(c)$ numbers of flagella adjusted by multiplying the percentage of each fraction by the net increase of flagellar number during incubation: that is, $(b) \times 1 \cdot 23$ for $2 \mathrm{hr}$ values and $\times \mathrm{I} \cdot 36$ for $3 \mathrm{hr}$.

\begin{tabular}{|c|c|c|c|}
\hline \multirow[b]{2}{*}{ Flagella shape } & \multicolumn{3}{|c|}{ Time (hr) incubated in RM (FPA) } \\
\hline & 0 & 2 & 3 \\
\hline Normal & $\begin{array}{lr}\text { (a) } & 1772 \\
\text { (b) } & 100 \\
\text { (c) } & 100\end{array}$ & $\begin{array}{c}935 \\
7 \mathrm{I} \cdot 2 \\
87 \cdot 6\end{array}$ & $\begin{array}{c}507 \\
50 \cdot 1 \\
68 \cdot 1\end{array}$ \\
\hline Heteromorphous & $\begin{array}{l}(a) \\
(b) \\
(c)\end{array}$ & $\begin{array}{l}32 \mathrm{I} \\
24 \cdot 5 \\
30 \cdot \mathrm{I}\end{array}$ & $\begin{array}{c}433 \\
42 \cdot 8 \\
58 \cdot 2\end{array}$ \\
\hline Curly & $\begin{array}{l}(a) \\
(b) \\
(c)\end{array}$ & $\begin{array}{l}57 \\
4 \cdot 3 \\
5 \cdot 3\end{array}$ & $\begin{array}{l}72 \\
7 \cdot 1 \\
9 \cdot 7\end{array}$ \\
\hline Total & $\begin{array}{ll}(a) & 1772 \\
(b) & 100 \\
(c) & 100\end{array}$ & $\begin{array}{r}1313 \\
100 \\
123\end{array}$ & $\begin{array}{r}1012 \\
100 \\
136\end{array}$ \\
\hline
\end{tabular}

increased $\mathrm{I} \cdot 23$-fold at $2 \mathrm{hr}$ and $\mathrm{I} \cdot 36$-fold at $3 \mathrm{hr}$, and the fractions of the newly formed flagella among them were therefore $18 \cdot 7 \%$ at $2 \mathrm{hr}$ and $26.5 \%$ at $3 \mathrm{hr}$. Changes in distribution of flagellar numbers per bacterium are shown in Fig. I. The rate of flagellar formation de novo in RM(FPA) was considerably lower than the rate of cell multiplication.

After FPA treatment, both curly flagella and heteromorphous ones, having both 
normal and curly waves on the same flagellum, appeared together with normal flagella. Heteromorphous flagella were normal at the region nearest the cell and curly at the distal end. Changes in the numbers of normal, curly and heteromorphous flagella during incubation in RM(FPA) are shown in Table $\mathrm{I}$, and the distributions of normal wave numbers among both normal and heteromorphous flagella are shown in Fig. 2; the number of wholly normal flagella with $\mathrm{I}$ to 4 waves decreased with passage of time while those of both curly and heteromorphous flagella increased.

\section{Table 2. Distribution of flagellar shape among Salmonella typhimurium LT 2 bacteria grown in RM(FPA)}

Numbers outside parentheses indicate the bacterial number at $2 \mathrm{hr}$, and inside the parentheses at $3 \mathrm{hr}$.

Flagellar number per cell

\begin{tabular}{|c|c|c|c|c|c|c|c|c|}
\hline \multirow[b]{2}{*}{ Curly } & \multirow{2}{*}{$\begin{array}{l}\text { Hetero- } \\
\text { morphous }\end{array}$} & \multicolumn{6}{|c|}{ Total (curly, heteromorphous and normal) } & \multirow{2}{*}{$\begin{array}{l}\text { Total cel } \\
\text { number }\end{array}$} \\
\hline & & 2 & 3 & 4 & 5 & 6 & 7 & \\
\hline \multirow[t]{4}{*}{0} & 0 & $23(19)$ & $36(13)$ & $23(6)$ & $19(0)$ & $9(0)$ & $2(1)$ & I I 2 (39) \\
\hline & I & $26(52)$ & $27(38)$ & 24 (17) & $13(5)$ & $9(0)$ & I (o) & $100($ I I 2) \\
\hline & 2 & $9(20)$ & $11(28)$ & $9(\mathrm{I} 4)$ & $13(7)$ & $8(\mathrm{I})$ & I (o) & $5 I(70)$ \\
\hline & 3 & - & $1(18)$ & $4(10)$ & $7(4)$ & I (I) & I (o) & $14(33)$ \\
\hline \multirow[t]{5}{*}{ I } & o & $4(8)$ & $5(4)$ & $4(7)$ & $2(0)$ & I (o) & $O(0)$ & $16(19)$ \\
\hline & I & $4(6)$ & $13(4)$ & $8(3)$ & $3(0)$ & $2(\mathrm{I})$ & I (o) & $3 I$ (I4) \\
\hline & 2 & - & I (7) & I (4) & $4(3)$ & $O(I)$ & $o(0)$ & 6 (I5) \\
\hline & 3 & - & - & $o(0)$ & $o(0)$ & $O(2)$ & $o(0)$ & $o(2)$ \\
\hline & 4 & - & - & - & $O(0)$ & $o(0)$ & I (o) & I (o) \\
\hline \multirow[t]{2}{*}{2} & 0 & (2) & I (I) & $o(0)$ & $o(0)$ & $o(0)$ & $O(0)$ & I (3) \\
\hline & I & - & $o(0)$ & I (I) & $o(I)$ & $1(0)$ & I (o) & $3(2)$ \\
\hline \multirow[t]{2}{*}{3} & I & - & - & $o(0)$ & $O(I)$ & $o(0)$ & $o(0)$ & $O(I)$ \\
\hline & Total & $66(107)$ & $95\left(\begin{array}{ll}\mathrm{I} & 3\end{array}\right)$ & $74(62)$ & 6I (2I) & 3 I (6) & $8(\mathrm{I})$ & $335(310)$ \\
\hline
\end{tabular}

As the curly waves were presumed to be newly formed during incubation in RM (FPA), pure curly flagella were formed de novo in RM(FPA). The incidence of wholly curly flagella $(4.3 \%$ at $2 \mathrm{hr}$ and $7 \cdot \mathrm{I} \%$ at $3 \mathrm{hr})$ was, however, less than that of the newly-formed fractions (I8.7\% at $2 \mathrm{hr}$ and $26.5 \%$ at $3 \mathrm{hr}$ ). Therefore, the remaining fractions of newly-formed flagella must be either normal or heteromorphous. Even though these fractions are all heteromorphous, $4 \mathrm{I} \cdot 2 \%(=100 \times[24 \cdot 5-(\mathrm{I} 8 \cdot 7-4 \cdot 3)] /$ $24.5)$ of heteromorphous flagella at $2 \mathrm{hr}$ and $54.7 \%(=100 \times[42 \cdot 8-(26 \cdot 5-7 \cdot \mathrm{I})] / 42 \cdot 8)$ at $3 \mathrm{hr}$ are estimated to have changed from normal flagella present at $\circ \mathrm{hr}$ to heteromorphous ones.

Distribution of curly and heteromorphous flagella among the bacteria grown in $R M(F P A)$. Distributions of the numbers of bacteria with numbers of normal, curly and heteromorphous flagella were scored in the 2 and $3 \mathrm{hr}$ samples. As shown in Table 2, curly and heteromorphous flagella were evenly distributed among the cells with different number of flagella. This may mean that every cell in RM(FPA) had an equal potentiality to produce curly waves.

Distribution of curly wave among heteromorphous flagella. The percentage of flagella with different numbers of curly waves was caluculated for each group having different numbers of normal waves (Fig. 3). All distributions fitted a Poisson distribution. The average numbers of curly waves per flagellum decreased with increase in normal 
wave number and reached zero for five to six normal waves (Fig. 4); the lines at 2 and $3 \mathrm{hr}$ were not paralled but convergent. The observed distribution of the pure curly fraction (Fig. $3 \mathrm{~A}$ ), compared with the theoretical one, indicated that a fraction of potentially active flagellum-forming apparatus did not produce flagella at all. If this
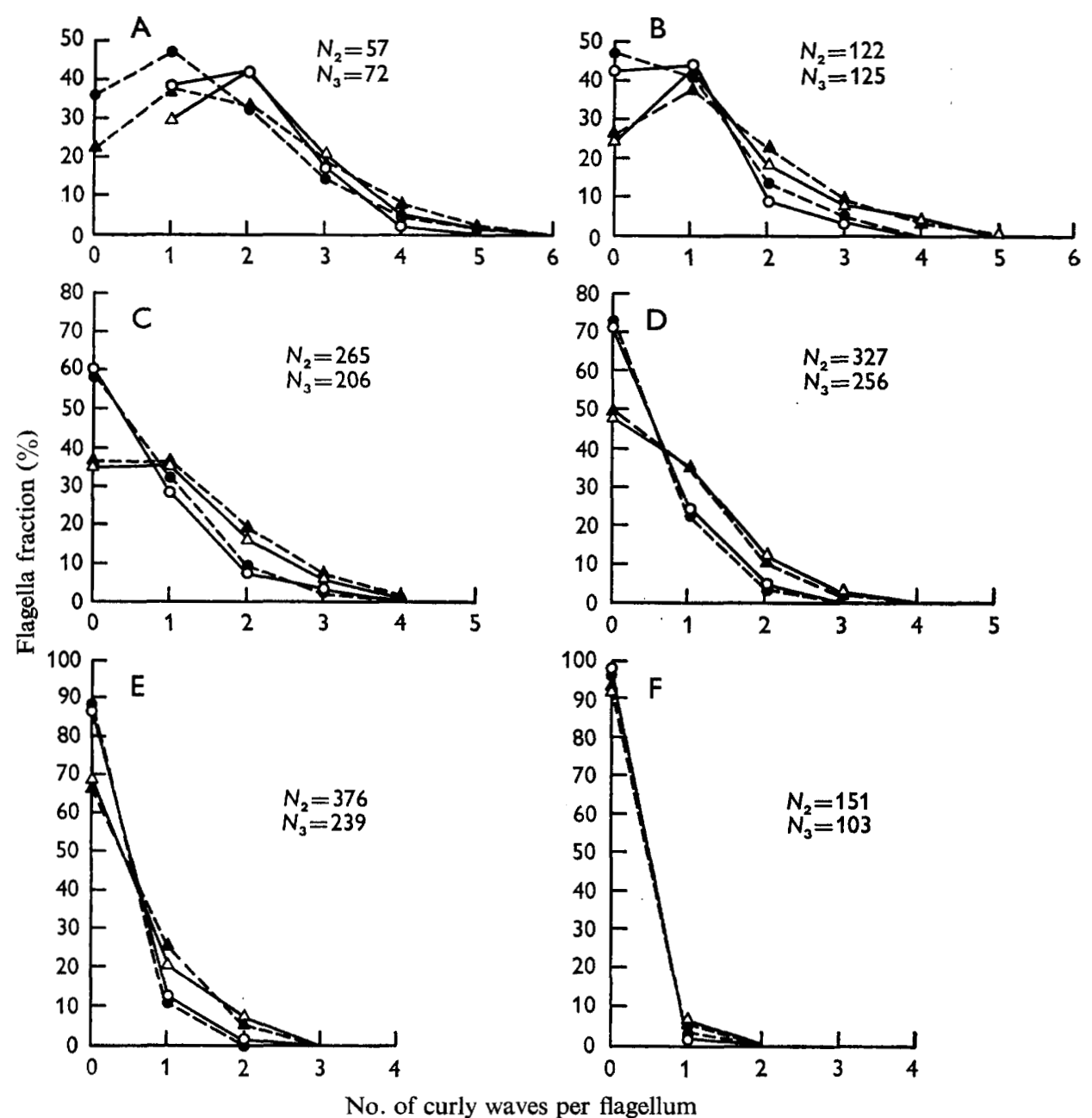

Fig. 3. Distribution of curly wave numbers in flagella with different normal wave number in Salmonella typhimurium LT 2 grown in RM (FPA): A, pure curly flagella; B, flagella with one normal wave; $\mathrm{C}$, with two normal waves; $\mathrm{D}$, with three normal waves; $\mathrm{E}$, with five normal waves; $\mathrm{F}$, with six normal waves. $\bigcirc$, observed value at $2 \mathrm{hr} ; \Delta$, at $3 \mathrm{hr}$;, Poisson distribution with the mean observed at $2 \mathrm{hr} ; \boldsymbol{\Lambda}$, at $3 \mathrm{hr} . N_{2}$, observed flagellar number at $2 \mathrm{hr} ; N_{3}$, at $3 \mathrm{hr}$.

null fraction is included in calculating the mean values, the percentages of pure curly flagella become smaller than those plotted in Fig. 3. A corrected mean $(m)$ was calculated from the mean $(n)$ obtained from the observed wave numbers in pure curly flagella by the following equation: $n=e^{-m} /\left(\mathrm{I}-e^{-m}\right)$ where $2^{-m}$ represents the null fraction. The $m$ values thus corrected were plotted in Fig. 4 by broken lines. 
Formation of curly and heteromorphous flagella in RM(FPA) by bacteria pre-incubated in saline. The foregoing experiment showed that more curly waves were formed in RM(FPA), the smaller the number of normal waves. However, we cannot decide whether the larger curly wave number, observed on the heteromorphous flagella, represents more growth or a tendency to grow curly waves at the tips of shorter flagella, because normal as well as curly waves increased considerably in RM(FPA) and it was impossible to differentiate normal waves newly grown in RM(FPA) from those present before treatment. To decrease the production of normal waves in RM(FPA) as much as possible, several different procedures were tried, and it was found that preincubation of bacteria in saline fulfilled the requirement.

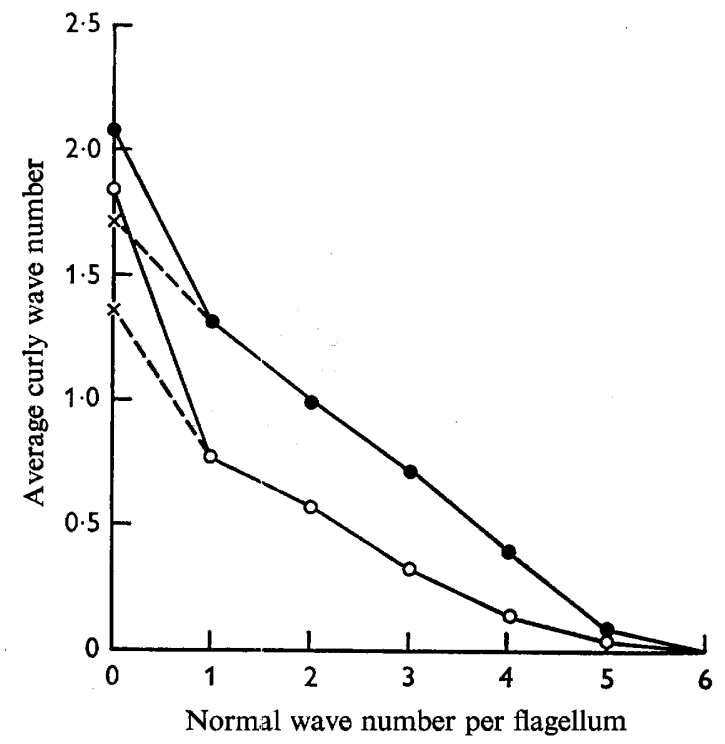

Fig. 4. Average number of curly waves in flagella with different number of normal waves in Salmonella typhimurium LT 2 grown in RM (FPA). $\bullet$, At $2 \mathrm{hr}$; $O$, at $3 \mathrm{hr}$; --, corrected values counting the null fraction estimated from the Poisson distribution.

Bacteria of strain LT 2 in late logarithmic growth were centrifuged and suspended in $5 \mathrm{ml}$. saline at $1 \cdot 9 \times 10^{8} / \mathrm{ml} .2 \cdot 5 \mathrm{ml}$. of the suspension was used for the experiment reported in the next section. The remaining $2.5 \mathrm{ml}$. was kept for $90 \mathrm{~min}$. at $23^{\circ}$, when the bacterial concentration increased to $2.4 \times 10^{9} \mathrm{cells} / \mathrm{ml}$. The number of viable bacteria measured on serial dilution plates was not significantly different from the total number. The suspension was then centrifuged and the pellet of bacteria suspended in $2.5 \mathrm{ml}$. of RM(FPA), diluted tenfold, and incubated $3 \mathrm{hr}$ at $37^{\circ}$. The flagellar shape and the distribution of flagellar number were examined before and after incubation.

During incubation, the concentration increased from $\mathrm{I} \cdot 8 \times 10^{8}$ to $2 \cdot 7 \times 10^{8} \mathrm{bacteria} / \mathrm{ml}$. Distributions of flagellar numbers at 0 and $3 \mathrm{hr}$ are shown in Fig. 5 and frequencies of normal, heteromorphous, and curly flagella are listed in Table 3. As in the earlier experiment, heteromorphous flagella were all curly distally and normal at the proximal end. The number of normal flagella at o hr was approximately the same as the summed number of normal and heteromorphous flagella at $3 \mathrm{hr}$. The distribution of normal 
wave number among normal and heteromorphous flagella and the fraction of wholly normal flagella among them are shown in Fig. 6. The distribution of normal waves was almost identical between o and $3 \mathrm{hr}$. Thus, both flagella newly formed in RM(FPA) and flagellar parts extended in RM(FPA) were almost all curly and the curly wave number may be regarded as the measure of the growth of flagella during incubation. The number of curly waves in each group of flagella with the same normal waves per flagellum with different normal wave numbers are shown in Fig. 8. As in the earlier

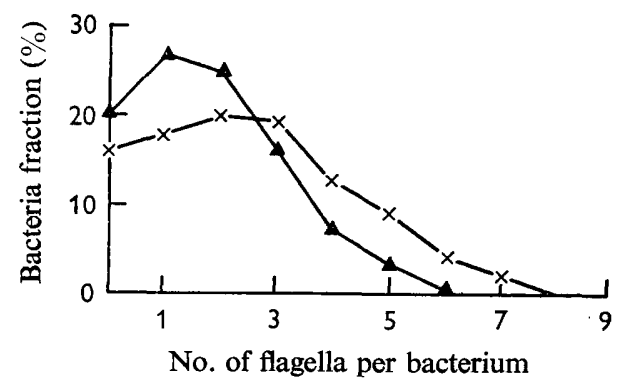

Fig. 5

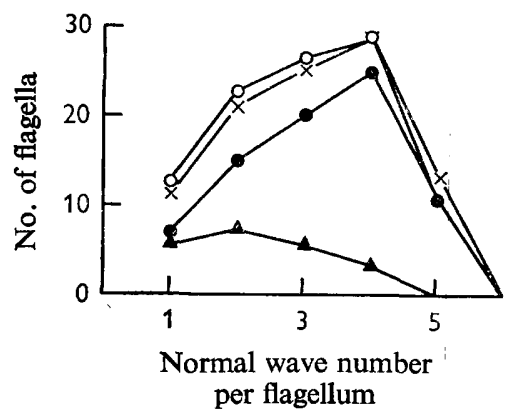

Fig. 6

Fig. 5. Changes in the distribution of flagellar number per bacterium during the growth of Salmonella typhimurium LT 2 in RM (FPA) after preincubation in saline for 90 min.: $\times$, at o hr; $\Delta$, at $3 \mathrm{hr}$.

Fig. 6. Distribution of the numbers of normal waves among flagella of Salmonella typhimurium LT 2 grown in RM (FPA) after preincubation in saline for $90 \mathrm{~min} .: \times$, normal flagella at $\circ \mathrm{hr}$;, , normal flagella at $3 \mathrm{hr} ; \boldsymbol{\Delta}$, heteromorphous flagella at $3 \mathrm{hr} ; \bigcirc$, normal plus heteromorphous flagella at $3 \mathrm{hr}$. The total number of flagella at o hr was taken as I00. The number of flagella at $3 \mathrm{hr}$ was adjusted by multiplying the percentage of each fraction by the net increase of flagellar number during incubation; thus, the total number at $3 \mathrm{hr}$ was taken as 106 (see Table 3).

Table 3. Flagellar shape of Salmonella typhimurium LT2 grown in $R M(F P A)$ after pre-incubation in saline

(a) Numbers of flagella counted on 400 bacteria; $(b)$ percentage of flagella of different shape in each incubation time; $(c)$ numbers of flagella adjusted by multiplying the percentage of each fraction by the net increase of flagella during the incubation: that is, $(b) \times 1 \cdot 06$ for $3 \mathrm{hr}$.

Time (hr) incubated in RM (FPA)

\begin{tabular}{lccc} 
Flagellar shape & \multicolumn{2}{c}{0} & 3 \\
Normal & $(a)$ & 992 & 510 \\
& $(b)$ & 100 & $72 \cdot 5$ \\
Heteromorphous & $(c)$ & 100 & 76.9 \\
& $(a)$ & 0 & 147 \\
Curly & $(b)$ & 0 & 20.9 \\
& $(c)$ & 0 & $22 \cdot 2$ \\
Total & $(a)$ & 0 & 46 \\
& $(b)$ & 0 & 6.5 \\
& $(c)$ & 0 & 6.9 \\
& $(a)$ & 992 & 703 \\
& $(b)$ & 100 & 100 \\
& $(c)$ & 100 & 106
\end{tabular}


experiment, the newly-grown curly portion was shorter in flagella with longer normal portions and become zero at around five normal waves.

The difference in growth among different lengths of flagella may occur for three reasons: (I) growth in RM(FPA) initiates later in longer flagella, (2) growth stops earlier in longer flagella in RM(FPA) because they reach their maximal length sooner; (3) growth rate declines with increase in length. If the first possibility held, flagellar growth after initiation would be the same, regardless the length of previously formed flagellum, and the lines at 2 and $3 \mathrm{hr}$ in Fig. 4 would be parallel. The convergence in Fig. 4 therefore excludes this possibility. The second possibility is also less plausible because, in both average and maximal length, the whole length (normal plus curly) of a flagellum is shorter in flagella with smaller number of normal waves (Table 4); that is, neither heteromorphous nor curly flagella had reached their maximal length during the $3 \mathrm{hr}$ incubation in RM(FPA). The remaining possibility, (3), fits the available data and may be accepted as the most reasonable.

Table 4. Average and maximal length of flagella with different numbers of normal waves in Salmonella typhimurium LT2 grown $3 \mathrm{hr}$ in $R M(F P A)$ after preincubation in saline

\begin{tabular}{|c|c|c|c|c|c|c|c|}
\hline & & \multicolumn{6}{|c|}{ Normal wave number } \\
\hline & & 0 & $\mathbf{I}$ & 2 & 3 & 4 & 5 \\
\hline Average & $\begin{array}{l}\text { Curly wave number } \\
\text { Flagellar length }(\mu)^{*}\end{array}$ & $\begin{array}{l}1 \cdot 38 \\
2 \cdot 6\end{array}$ & $\begin{array}{l}0 \cdot 73 \\
4 \cdot 4\end{array}$ & $\begin{array}{l}0.44 \\
6.8\end{array}$ & $\begin{array}{l}0.25 \\
9.5\end{array}$ & $\begin{array}{l}0.08 \\
12 \cdot 2\end{array}$ & $\begin{array}{l}0.00 \\
15.0\end{array}$ \\
\hline Maximal & $\begin{array}{l}\text { Curly wave number } \\
\text { Flagellar length }(\mu)^{*}\end{array}$ & $\begin{array}{l}4 \\
7 \cdot 6\end{array}$ & $\begin{array}{l}3 \\
8 \cdot 7\end{array}$ & $\begin{array}{l}3 \\
11 \cdot 7\end{array}$ & $\begin{array}{c}2 \\
12 \cdot 8\end{array}$ & $\begin{array}{c}1 \\
13.9\end{array}$ & $\begin{array}{c}0 \\
15.0\end{array}$ \\
\hline
\end{tabular}

* Normal wave number $\times$ normal spiral unit length $(3 \cdot 0 \mu)+$ curly wave number $\times$ curly spiral unit length $(1 \cdot 9 \mu)$

Growth of flagella shortened by mechanical breakage. The decline in growth rate of flagella as their length increased, may occur (I) because the flagellum-forming apparatus at the base of each flagellum 'ages', or (2) because the growth rate depends on the distance between the flagellin factory, probably at the base of each flagellum, and the site of flagellin polymerization at the tip of each flagellum.

Growth of flagella which had been shortened by mechanical breaking was examined in parallel with the earlier experiments. If hypothesis (I) is correct, mechanically shortened flagella should grow more slowly than intact flagella of the same length; whereas, on hypothesis (2) both flagella should grow at approximately the same speed unless the mechanical shock is unfavourable to the polymerization of flagellin.

Bacterial suspension in saline $(2.5 \mathrm{ml}$.), left aside in the earlier experiment, was deflagellated at $23^{\circ}$. The bacterial concentration increased during shaking from $\mathrm{I} \cdot 9 \times 10^{9}$ to $2.5 \times 10^{9}$ bacteria $/ \mathrm{ml}$.: values not significantly different from those of unshaken bacteria. The bacteria were suspended in RM(FPA), diluted tenfold, and the bacterial concentration rose from $1.8 \times 10^{8}$ to $2.4 \times 10^{8}$ bacteria $/ \mathrm{ml}$. in $3 \mathrm{hr}$. The total number of flagella per 400 bacteria at o hr in RM(FPA) was 335 ; i.e. $66 \cdot 2 \%$ of the 992 flagella in the unshaken control were removed by shaking. Comparison of normal wave numbers at $\mathrm{o} \mathrm{hr}$ in the previous and the present experiments (Fig. 3, 9) indicates that flagella with more than three waves were almost all broken by shaking and converted to zero to two wave flagella. 
After $3 \mathrm{hr}$, heteromorphous and curly flagella appeared; heteromorphous flagella were curly at the distal portions. The normal wave distributions (Fig. I0) were not significantly different at $\mathrm{O}$ and $3 \mathrm{hr}$, indicating that flagella formed in RM(FPA) were almost all curly.

The distribution of curly waves on flagella with different numbers of normal waves followed a Poisson distribution (Fig. 7). Among short flagella in shaken bacteria both

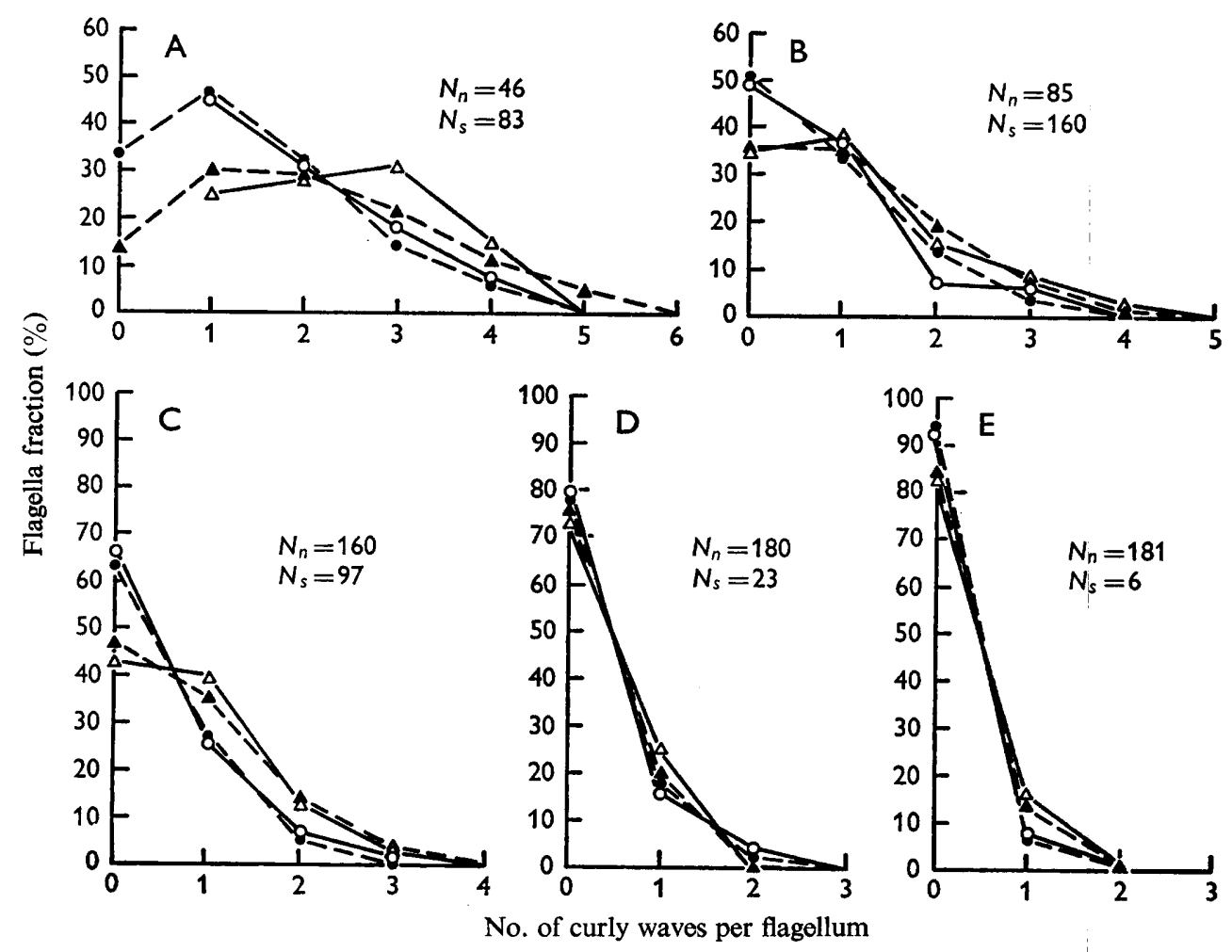

Fig. 7. Distribution of the number of curly waves in flagella with different numbers of normal waves in Salmonella typhimurium LT 2 grown in RM (FPA) after preincubation in saline or after mechanical shaking for $90 \mathrm{~min}$.: A, pure, curly flagella; B, flagella with one normal wave; $\mathrm{C}$, with two normal waves; $\mathrm{D}$, with three normal waves; $\mathrm{E}$, with four normal waves. $O$, observed value at $3 \mathrm{hr}$ in RM (FPA) after preincubation in saline; $\triangle$, after shaking. Poisson distribution with the same mean as that observed value on unshaken bacteria; $\boldsymbol{\Lambda}$, on shaken bacteria. $N_{n}$, number of flagella observed on unshaken bacteria; $N_{s}$, number of flagella observed on shaken bacteria.

intact and broken flagella are inferred to be mixed. For example, I I2/400 bacteria had flagella with one normal wave at o hour in the unshaken sample, while the number in the shaken sample was $206 / 400$ bacteria. Therefore, at least $45.6 \%$ of the flagella with one normal wave were produced by breaking longer flagella.

The average number of curly waves per flagellum with different number of normal waves is shown in Fig. 8. As in the two earlier experiments, newly grown curly waves were shorter in flagella with more normal waves and reached zero at about five normal waves. In favour of hypothesis (2) the average numbers of curly wave in short flagella 
were not smaller, but somewhat larger, in the shaken sample as compared with those in the intact one.

Shapes of flagella grown in mixed culture of normal and curly flagellar strains of Salmonella. For flagella to grow at their tips, flagellin synthesized in the bacterial bodies must be transported to the tip. How is this done? The flagellins of normal and curly flagella can copolymerize and form curly flagella when mixed in the proportions, $\mathrm{I} / \mathbf{I}$ to $\mathrm{I} / 5(\mathrm{w} / \mathrm{w})$ (Asakura, Eguchi \& Iino, I966). If flagellin molecules are excreted from the bacterial bodies into the medium, normal bacteria should form curly flagella when grown in mixed culture with an appropriate concentration of curly mutant bacteria.

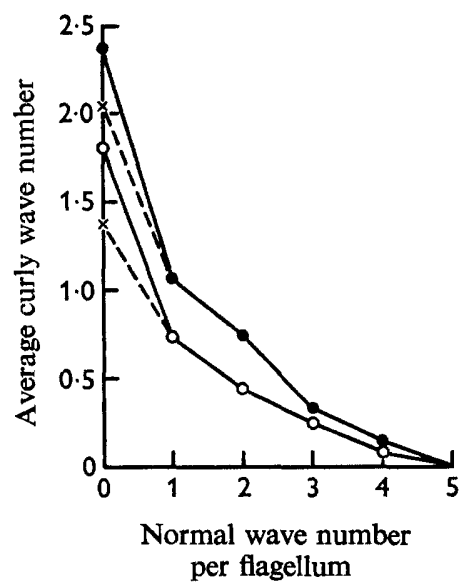

Fig. 8

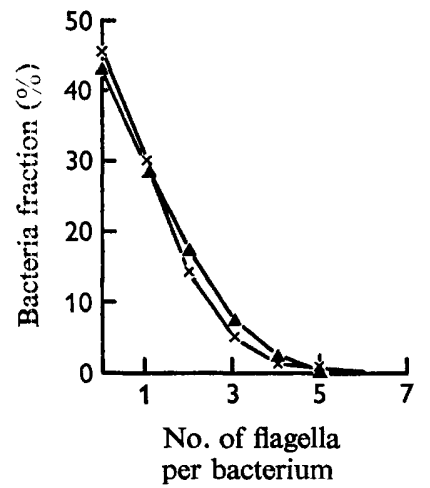

Fig. 9

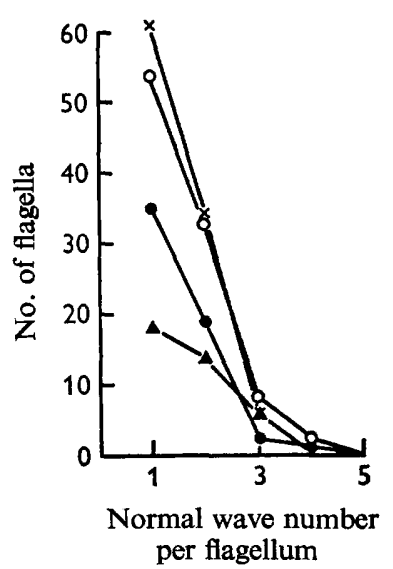

Fig. 10

Fig. 8. Average number of curly waves of a flagellum with different numbers of normal waves in Salmonella typhimurium LT 2 grown in RM (FPA) after pre-incubation in saline or after mechanical shaking: $0,3 \mathrm{hr}$ in RM(FPA) after pre-incubation in saline for $90 \mathrm{~min}$.; $\boldsymbol{O}$, after shaking in saline for $90 \mathrm{~min}$; $\times$ corrected values counting the null fraction estimated from the Poisson distribution.

Fig. 9. Changes in the distributuion of flagella numbers per bacterium during growth of Salmonella typhimurium LT 2 in RM (FPA) after mechanical shaking in saline for 90 min.: $\times, \mathrm{o} \mathrm{hr} ; \boldsymbol{\Delta}, 3 \mathrm{hr}$.

Fig. 10. Distribution of the numbers of normal waves on flagella of Salmonella typhimurium LT 2 grown in RM (FPA) after mechanical shaking: $\times$, normal flagella at $\circ \mathrm{hr}$; 0 , normal flagella at $3 \mathrm{hr} ; \boldsymbol{\Lambda}$, heteromorphous flagella at $3 \mathrm{hr}$; $\bigcirc$, normal plus heteromorphous flagella at $3 \mathrm{hr}$. Total number at $\mathrm{hr}$ was taken as 100 . Number at $3 \mathrm{hr}$ was adjusted by multiplying the percentage of each fraction by the net increase of flagella number during incubation. Thus, the total number of flagella at $3 \mathrm{hr}$ was taken as 150 .

Two strains were used whose flagellins are known to copolymerize (Asakura et al. 1966): SJ 25, producing normal flagella, and sJ 30, a curly mutant. Equal volumes of these cultures were transferred to fresh broth and cultivated at $37^{\circ}$. At 0 and $3 \mathrm{hr}$ of cultivation, part of each culture was fixed with formalin and the flagella examined. The proportion of normal to curly bacteria in the mixture was also estimated by plating a sample on semisolid media; normal bacteria form swarms while curly ones grow in compact colonies (Iino, 1962). As seen in Table 5, the numbers of both bacteria and flagella increased approximately $\mathrm{I} \cdot 5$-fold. The flagella of salmonellas are 
distributed to both daughter bacteria at division (Quadling \& Stocker, 1962). Therefore about one-third of the flagella present at $3 \mathrm{hr}$ were presumably produced during growth and distributed among the bacteria, coexisting with ready-made flagella on a cell. However, the flagella carried by a given bacterium were either normal or curly, and no heteromorphous flagella were detected among 400 cells examined.

\section{Table 5. Shape of flagella grown in mixed culture of normal and curly flagellar strains of Salmonella}

\begin{tabular}{|c|c|c|c|c|}
\hline \multirow{2}{*}{$\begin{array}{l}\text { Incubation } \\
\text { time (hr) }\end{array}$} & \multirow[b]{2}{*}{ Type of bacteria } & \multirow{2}{*}{$\begin{array}{c}\text { Number } \\
\text { of bacteria } \\
\text { per } \mathrm{ml}\left(\times 10^{8}\right)^{*}\end{array}$} & \multicolumn{2}{|c|}{ Number of flagella $\uparrow$} \\
\hline & & & Per bacterium & Per $\mathrm{ml}\left(\times 10^{8}\right)$ \\
\hline \multirow[t]{3}{*}{0} & Normal & $1 \cdot 4$ & $2 \cdot 9$ & $4 \cdot I$ \\
\hline & Curly & $\mathbf{I} \cdot \mathbf{I}$ & $3 \cdot 0$ & $3 \cdot 3$ \\
\hline & Heteromorphous & 0 & - & - \\
\hline \multirow[t]{3}{*}{3} & Normal & $2 \cdot 0$ & $3 \cdot I$ & $6 \cdot 2$ \\
\hline & Curly & $1 \cdot 7$ & $3 \cdot 2$ & $5 \cdot 4$ \\
\hline & Heteromorphous & 0 & - & - \\
\hline
\end{tabular}

* Measured on semisolid media. † Average values calculated from the observation of 400 stained cells.

\section{DISCUSSION}

The present experiments show that Salmonella flagella grow at their free ends. This agrees with the polarity of flagellar growth in vitro (Asakura et al. 1968). Thus, the basic molecular mechanism of flagellar growth in vivo may be homologous with that of polymerization of flagellin molecules into flagella in vitro. As for the initiation of flagellar formation de novo, there still exists a gap between flagellar reconstitution in vitro and flagellar growth in vivo. In vitro, a fragment of flagellum is required as a nucleus of polymerization under ordinary physiological conditions; while in vivo, flagellar formation de novo from the bacteria having no flagellar fragments was demonstrated in phage-mediated transduction of flagellation genes to non-flagellate mutants (Iino \& Enomoto, I966). The identification of the initiator of polymerization in vivo which replaces the role of flagellar fragments in vitro is essential for a full understanding of flagellar morphogenesis.

The present experiments show that flagellin molecules are unlikely to be excreted into media and used for the growth of flagella. The remaining pathway by which flagellin molecules can reach the tip of a growing flagellum is the tubular hole of the flagellum. A flagellar fibre is a tubular thread consisted of a monolayer of flagellin molecules. Its central hole has a diameter of approximately $60 \AA$; the space is large enough to pass a flagellin molecule whose diameter is 40 to $45 \AA$ (Kerridge, Horne \& Glauert, I962; Lowy \& Hanson, 1965). If this be the case, how and from where do flagellin molecules receive energy to travel from the base of a flagellum all the way to its tip? At present, we know nothing of the mechanism which provides transport energy for flagellin. The proximal part of a flagellum ends as a structure called a 'hook', connected to a spherical granule, called a 'basal granule' (Abram, Koffler \& Vatter, I965; Hoeniger, Iterson \& Zanten, I966; Iterson, Hoeniger \& Zanten, 1967; Kerridge et al. 1962; Lowy, 1965) These basal structures are presumed to be responsible for the synthesis of flagellin and initiation of flagellar formation as well as flagellar movement. They might also be promoters of flagellin transport; for example, accumulation of 
flagellin molecules in the basal structure might cause the efficient diffusion or pushing of the molecules through the hole to the tip of the flagellum.

From the observations of reappearance of flagellate bacteria in deflagellated suspensions of salmonellas, Stocker \& Campbell (1959) presented evidence that a flagellum gradually elongates for a limited period and thereafter persists without further elongation, and also that the rate of growth of flagella is unaffected by deflagellation. The present experiments support these conclusions and further show that, during flagellar growth in vivo, the speed of growth decreases gradually with increase of the length of flagella, reaching zero at around $15 \mu$.

As suggested from reconstitution experiments in vitro, the distal ends of flagella can grow infinitely as long as the proper concentration of flagellin molecules is present in the reaction mixture (Asakura, Eguchi \& Iino, 1964). The decline of the growth rate in vivo may therefore be caused by a decrease in the supply of flagellin molecules to the tip, the polymerization site of flagellin. This decline in growth rate depended not on functional decline of the flagellum-forming apparatus by ageing but on the distance between the growing site and the base of the flagellum, which would be consistent with the view that the growth rate depended on the distance to be traversed by flagellin molecules through the tubular hole of a flagellum.

The length of flagella grown on bacterial bodies has an upper limit. In Salmonella, the greatest number of waves seen on the wild-type strain was between five and six normal waves in ordinary cultural conditions. This maximum corresponds to that at which the growth rate of flagella reached zero in the present experiments. It is quite plausible that the mechanism as determining the decline in growth rate of flagella also plays an important role in determining flagellar length in growing bacteria. This postulate does not of course necessarily exclude the possibility of functional ageing of the flagellum-forming apparatus (Stocker \& Campbell, 1959) but such ageing might not be the primary cause of the gradual decline of the growth rate of extending flagella.

Contribution from the National Institute of Genetics, Misima, Japan, no. 707. This investigation was supported by a grant from the Research Fund of Ministry of Education of Japan. The author would like to thank Miss Utako Ogino for her technical assistance.

\section{REFERENCES}

Abram, D., Koffler, H. \& VATTER, A. E (1965). Basal structure and attachment of flagella in cells of Proteus vulgaris. J. Bact. 90, 1337.

AsAKURA, S., EGUCHI, G. \& IINO, T. (1964). Reconstitution of bacterial flagella in vitro. J. molec. Biol. Io, 42.

Asakura, S., EgUCHI, G. \& InNo, T. (1966). Salmonella flagella: in vitro reconstitution and over-all shapes of flagellar filaments. J. molec. Biol. 16, 302.

AsakuRA, S., EgUCHI, G. \& IINo, T. (1968). Unidirectional growth of Salmonella flagella in vitro. $J$. molec. Biol. 35, 227.

Hoeniger, J. F. M., ITERSON, W. van \& ZANTEN, E. M. vaN (I966). Basal bodies of bacterial flagella in Proteus mirabilis. II. Electron microscopy of negatively stained material. J. Cell Biol. 31, 603.

IINo, T. (1962). Curly flagellar mutants in Salmonella. J. gen. Microbiol. 27, I67.

InNo, T. \& Еломото, M. (1966). Genetical studies of non-flagellate mutants of Salmonella. J. gen. Microbiol. 43, 315.

ITERSON, W. vaN, HoENIGer, J. F. M. \& ZANTEN, E. N. vAN (1967). Basal bodies of the flagella and particular microtubules in swarmers of Proteus mirabilis. Antonie van Leeuwenhoek 33, 22 I. 
KERRIDGe, D. (1959a). The effect of amino acid analogues on the synthesis of bacterial flagella. Biochim. biophys. Acta 31, 579.

KERRIDGE, D. (I959b). Synthesis of flagella by amino acid-requiring mutants of Salmonella typhimurium. J. gen. Microbiol. 21, 168.

KERRIDGe, D. (1960). The effect of inhibitors on the formation of flagella by Salmonella typhimurium. J. gen. Microbiol. 33, 519.

Kerridge, D., Horne, R. W. \& Glauert, A. M. (1962). Structural components of flagella from Salmonella typhimurium. J. molec. Biol. 4, 227.

LEIFSON, E. (195I). Staining, shape and arrangement of bacterial flagella. J. Bact. 62, 377.

Lowy, J. (1965). Structure of the proximal ends of bacterial flagella. J. molec. Biol. 14, 297.

LOWY, J. \& HANSON, J. (1965). Electron microscope studies of bacterial flagella. J. molec. Biol. Ir, 293

QuAdLING, C.\& STOCKER, B. A. D. (1962). An environmentally-induced transition from the flagellated to the non-flagellated state in Salmonella typhimurium: the fate of parental flagella at cell division. J. gen. Microbiol. 28, 257.

Stocker, B. A. D. \& Campbell, J. C. (1959). The effect of non-lethal deflagellation on bacterial motility and observations on flagellar regencration. J. gen. Microbiol. 20, 670. 